\title{
The earliest occupation of North-Africa: the Moroccan perspective
}

\author{
J.P. Raynal ${ }^{\mathrm{a}, *}$, F.Z. Sbihi Alaoui ${ }^{\mathrm{b}}$, D. Geraads ${ }^{\mathrm{c}}$, L. Magoga ${ }^{\mathrm{d}}$, A. Mohi ${ }^{\mathrm{e}}$ \\ a'Université de Bordeaux 1, UMR 5808 CNRS, et Mission "Littoral", Talence, France \\ 'Institut National des Sciences de l'Archéologie et du Patrimoine, Ministère des Affaires Culturelles, Rabat, Morocco \\ 'Musée de l'Homme, UMR 152 CNRS, Paris (France) et Mission "Littoral", France \\ 'Mission "Littoral", Vichy, France \\ e Direction du Patrimoine, Inspection des Monuments et des Sites, Casablanca, Morocco
}

\begin{abstract}
The long sequence at Casablanca covers the past 5.5 Ma. The oldest lithic assemblages are found in Late Lower Pleistocene deposits, ca. $1 \mathrm{Ma}$, in unit L of Thomas Quarry 1, and consist of Acheulean artefacts made from quartzite and flint. The first human remains discovered in this area were found in younger Middle Pleistocene deposits and cover an important period of human evolution between Homo erectus and modern Homo. They are associated with Acheulean artefacts and rich faunal assemblages in caves (Littorina Cave at Sidi Abderrahman, caves at Thomas Quarries 1 and 3). The variability of Acheulean assemblages is well documented following recent excavations in various sites around the well-known locality of Sidi Abderrahman (Bears Cave, Cap Chatelier, Unit L and Hominid Cave at Thomas Quarry 1, Rhino Cave at Oulad Hamida Quarry 1, Sidi Abderrahman Extension and Sidi Al Khadir open-air sites). The Casablanca sequence offers useful data for comparison with those from other African areas where hominids appeared and developed, and should thus be considered in the debate on the earliest occupation of Europe. (C) 2001 Elsevier Science Ltd and INQUA. All rights reserved.
\end{abstract}

\section{Introduction}

It was a stroke of luck for archaeologists that Sultan Moulay Abdelaziz decided to build a modern harbor at Casablanca. Work began in 1907, and large quarries were immediately dug. The ocean destroyed the work twice, but it was continued and considerably extended. In 1913, the French company, Schneider, was given the contract and in 1919, it was decided that rocks would be used to build the jetties instead of concrete, in part due to the "excellent quarry at Sidi Abderrahman". Archaeological discoveries followed. Only a few cities in the world can claim such an amazing heritage hidden below their streets, a heritage difficult to preserve (Raynal and Geraads, 1993), and many researchers have contributed towards bringing it to light, through outstanding joint projects (including Neuville and Ruhlman, 1941; Lecointre, 1952; Gigout, 1956; Biberson, 1961a). We will give here only a brief overview of the diversity of these endeavors.

A joint Moroccan-French research program began in 1978 in the Casablanca area, well known for its pre-

\footnotetext{
* Corresponding author.
}

historic heritage and its well-preserved Quaternary sequences (Fig. 1). This has allowed the stratigraphic reappraisal in particular of the classic sites, among which, the Thomas Quarry sites had earlier produced several hominid remains (Geraads, 1980; Geraads et al., 1980; Debénath et al., 1982). In Thomas Quarry 1, archaeological elements dating to the Lower Acheulean have been discovered since 1986. Several excavations have also been carried out at different Middle Pleistocene sites: Rhino Cave at Oulad Hamida 1 Quarry, Bear Cave and Cap Chatelier at Sidi Abderrahman, and the Sidi Abderrahman Extension (Raynal et al., 1995). Moreover, new and important paleontological sites have been discovered in the older part of the sequence, dated between 2.4 and 5.5 Ma. They provide a considerable amount of new information on biological environments for these key periods.

Between Wadi Mellah to the northeast and Dar Bou Azza to the southwest, the hinterland of Casablanca is characterized by a series of large barrier systems subparallel to the present-day Atlantic coast. Intertidal depositional units, dune formations characteristic of regressive sequences, alteration facies (karsts, paleosols), and reworked deposits are associated with each of these morphological units. Stretching from $180 \mathrm{~m}$ a.s.l., down 


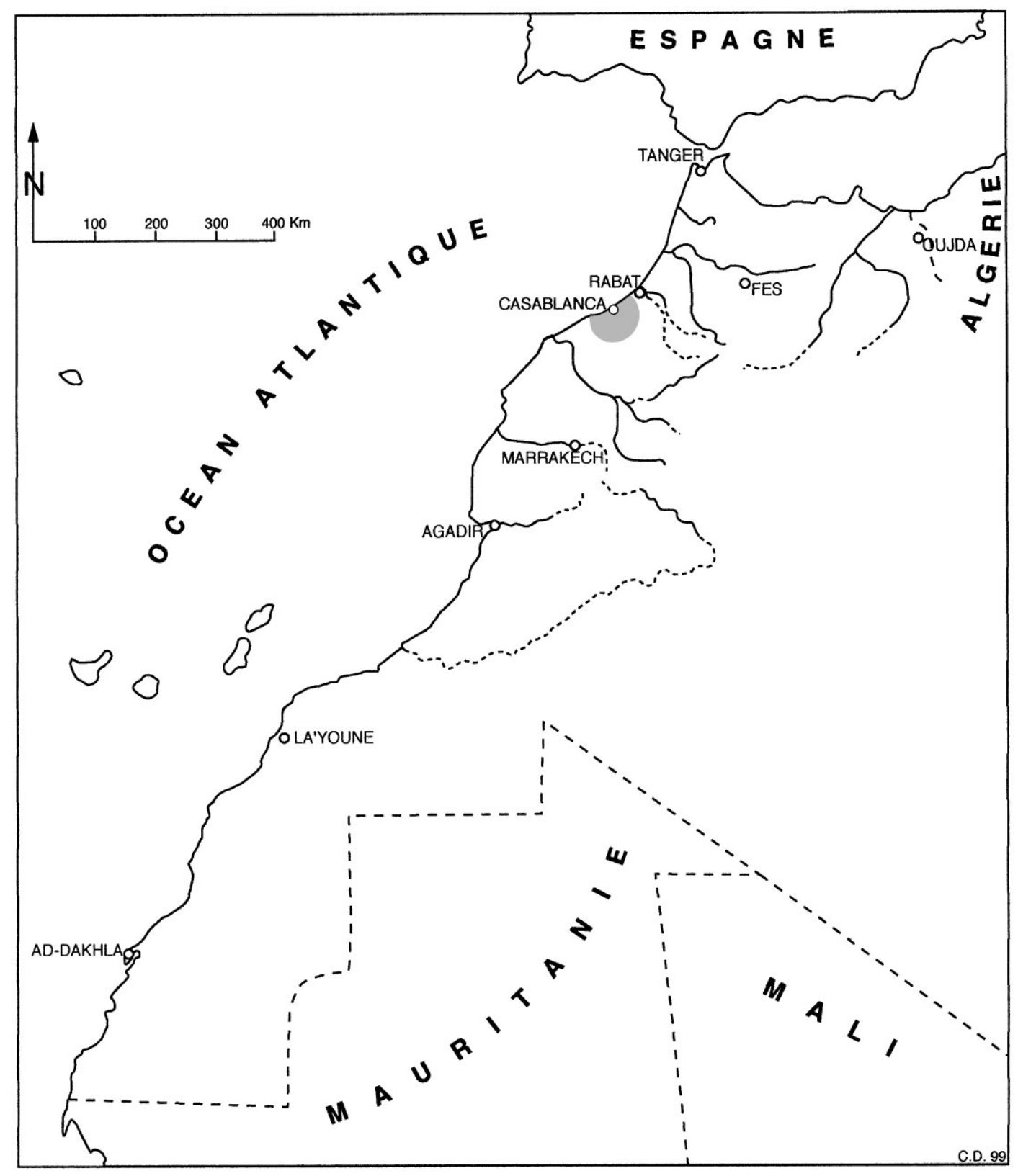

Fig. 1. Location map.

to the current sea level, these terraces form the long "Quaternary sequence" of Casablanca (Biberson, 1961a,b; Stearns, 1978). The long sequence of Casablanca is an exceptional record of global oceanic level variations relative to the fluctuations of the global glaciation in the high latitudes since the final Miocene. Age estimates for the different phases of this sequence have been established by various methods: lithostratigraphy, biostratigraphy, absolute dating (OSL, ESR), paleomagnetism, and aminochronology (Texier et al., 1985, 1987, 1994; Occhietti et al., 1993; El Graoui, 1994; Lefèvre et al., 1994). The biological and chronostratigraphical framework for prehistoric Meseta is now much more firmly established than it was just $10 \mathrm{yr}$ ago (Raynal et al., 1995) (Tables 1 and 2). It can now be compared to the East African one. Still it needs refining, and could indeed be improved, in particular for the Lower Pleistocene.

\section{Mio-Pliocene environments}

Mio-Pliocene environments are characterized as extremely rich paleontological sites, for example, Lissasfa, and Ahl Al Oughlam. These have not yet yielded hominid remains or artefacts - only geofacts. This is the first point to be stressed: no ancient pebble-tool culture has 


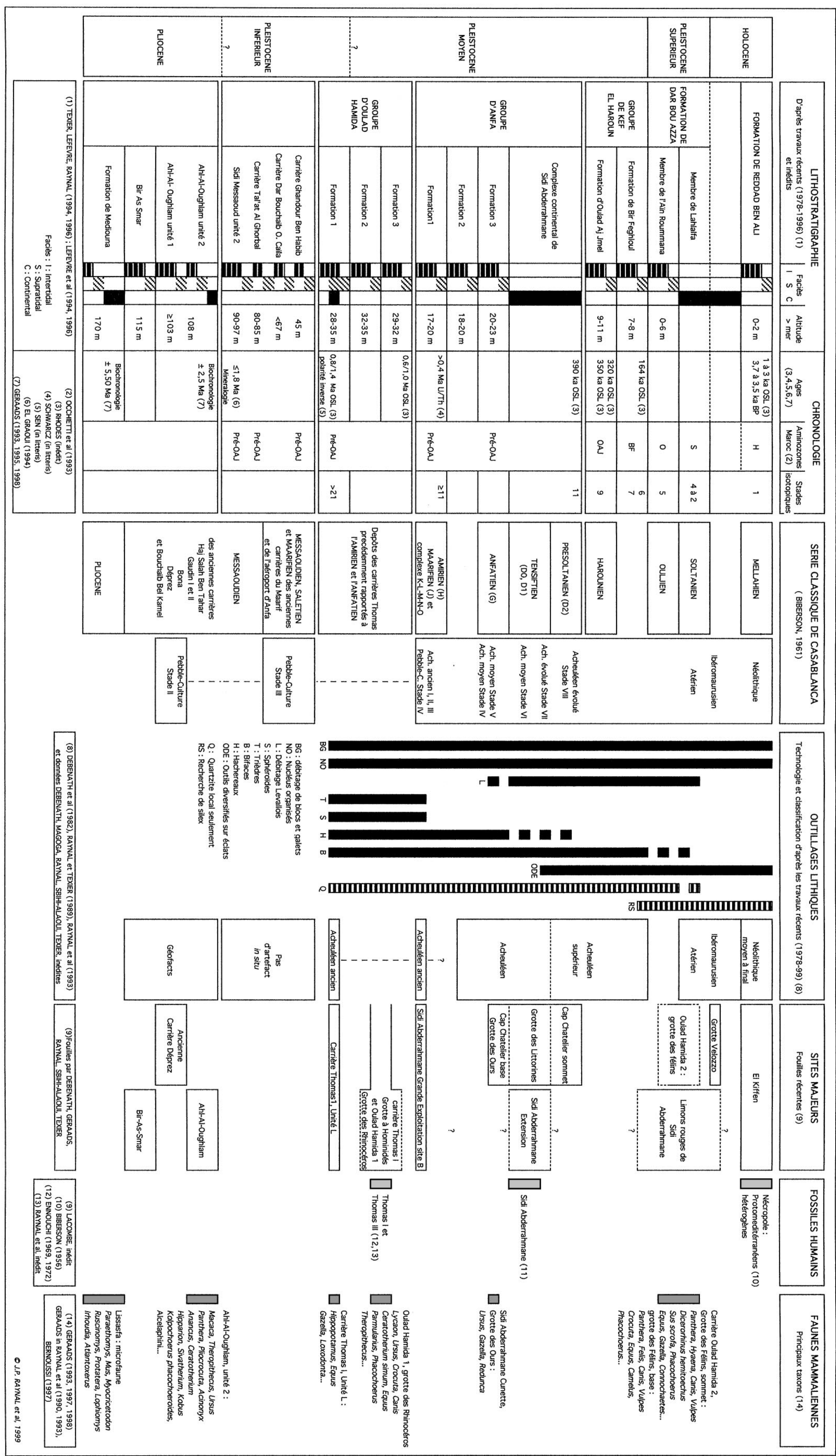


Table 2

The Casablanca faunal sets in a revised biostratigraphy of North-African faunas by Geraads

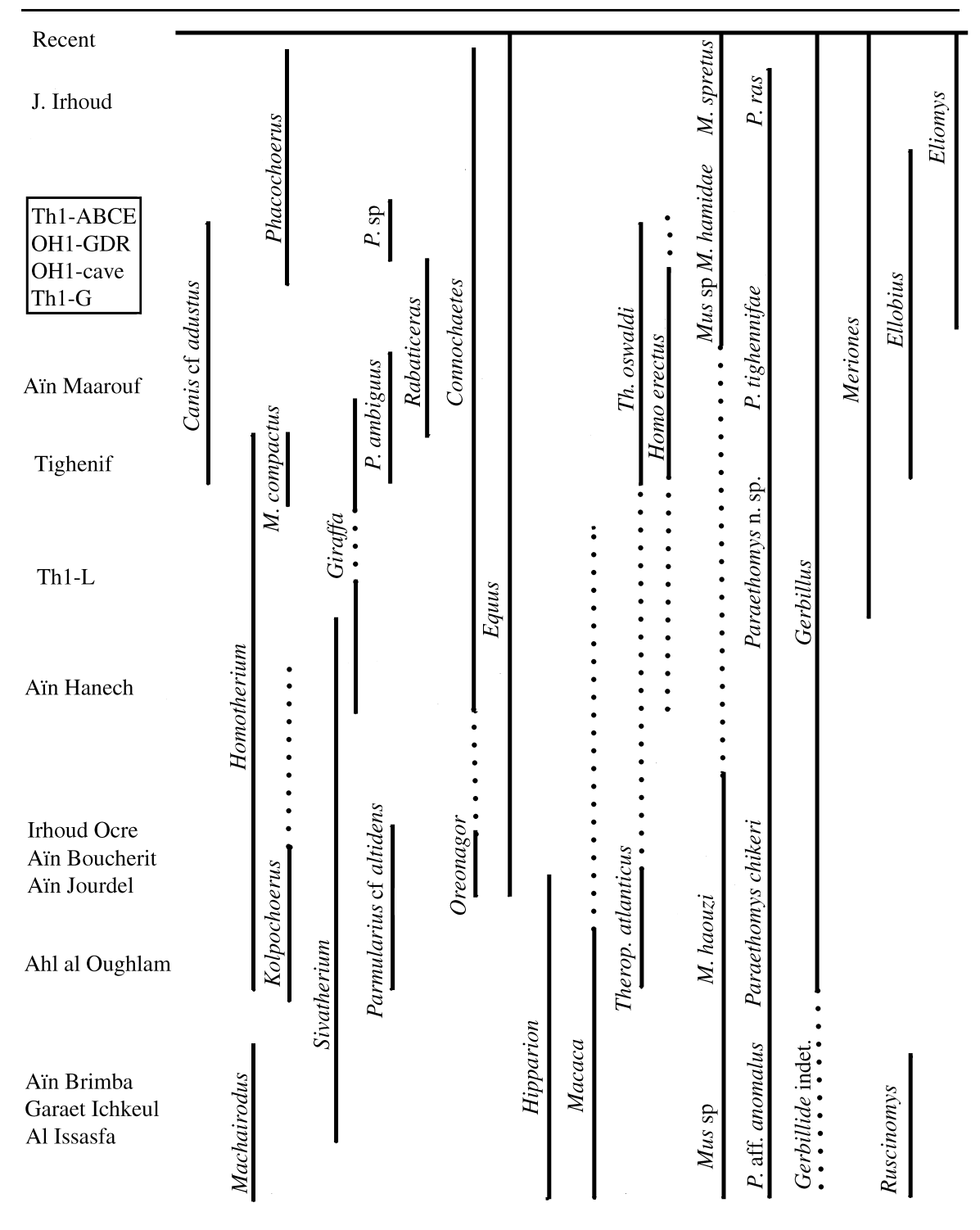

yet been discovered in Morocco. None of the sites previously described by Biberson as illustrative of the different stages of pebble-culture can stand up to a detailed analysis.

The bottom of the sequence has been dated at the locality of Lissasfa, discovered in 1995 (Geraads, 1998; Raynal et al., 1999). This is a fissure filling in an open quarry south of Casablanca and about $12 \mathrm{~km}$ from the present-day shoreline. It has yielded a few large mammal remains (cf. Sivatherium sp., Canid indet.) and an abundant collection of micro-mammals, such as Chiroptera, Insectivora, and many Rodents, of which the following have the greatest significance biochronologically:

- the Murid Paraethomys looks different from all other previously described species of this genus, but is remi- niscent of those from Spanish sites close to the MioPliocene boundary;

- the genus Myocricetodon, although very rare, points to a Miocene age, as it has almost never been found in the Pliocene;

- the Gerbillid Protatera has a very peculiar dental morphology, but looks slightly more derived than other Mio-Pliocene species;

- the Cricetid Ruscinomys, very rare in North Africa, is very primitive, as evidenced by its large third molars.

With four new species, the Rodent fauna of Lissasfa is too original to be easily correlated with any previously established biochronological scale, such as that provided by Coiffait-Martin (1991). The site cannot be older than the late Miocene, because of the occurrence of Mus and 
Paraethomys, but is not more recent than the early Pliocene, because of the occurrence of Myocricetodon, a primitive Ruscinomys, and due to the absence of Golunda. Finally, this association suggests an age near the Mio-Pliocene boundary, in the vicinity of 5.5 Ma. The occurrence of these animals also indicates a very open vegetation setting, analogous to that recognized in the Upper Pliocene at Ahl Al Oughlam, and related to the global climatic crisis of $2.4 \mathrm{Ma}$. The paleontological data from Lissasfa point towards a biostratigraphic dating based on the long sequence at Casablanca, which begins at the Mio-Pliocene boundary, in a regional climate context tending towards aridity, synchronous with a generalized lowering of the marine level (Messinian crisis).

The top of the Mio-Pliocene part of the sequence is illustrated by the richest paleontological site in the Casablanca area, and one of the richest in the whole of Africa: Ahl al Oughlam near Tit Mellil, discovered in 1985 and regularly excavated since 1989 (Raynal et al., 1990; Geraads et al., 1998). It has yielded more than 50 species of mammals, including for the first time in North Africa, a direct association of rich micro- and macrofauna (Geraads, 1993a, 1995, 1996, 1997; Geraads and Amani, 1997, 1998; Alemseged and Geraads, 1998; Geraads and Metz-Muller, 1999). This makes the site of Ahl al Oughlam by far the best reference locality for the North-African Plio-Pleistocene. Although comparison is not straightforward as all North African sites of this period are much poorer, the fauna allows a precise chronological placement of these fissure fillings, later in age than the marine level that yielded Biberson's so-called pebble-tool culture:

- numerous Equid remains all belong to the three-toed Hipparion and the absence of Equus is not in doubt. The latter genus was probably widespread in Europe and Africa by about $2.5 \mathrm{Ma}$, and an age of $2.2 \mathrm{Ma}$ for Ahl al Oughlam is certainly a minimum estimate;

- the Suid Kolpochoerus is specifically distinct from East-African forms but, assuming a similar rate of dental evolution, Ahl al Oughlam compares favorably with Omo member D, at ca. $2.4 \mathrm{Ma}$;

- the Carnivores are more diverse than in any other African locality, they are reminiscent of those of the Middle/Upper Pliocene East African sites, small Hyenas, Acinonyx, and Panthera;

- Bovids are slightly more primitive than those of the Plio-Pleistocene boundary in East Africa, but the Giraffid Sivatherium has clearer Pliocene affinities;

- Rodents, for example Paraethomys, are slightly more primitive than those of Irhoud Ocre, a site probably dating from the latest Pliocene.

Thus, on the whole, the fauna indicates a very open vegetation environment, related to the global climatic crisis of $2.4 \mathrm{Ma}$. Hominids are not present at Ahl Al Oughlam at this time. Considering that no artefacts have been found in Upper Pliocene formations - only geofacts - there is for now no clear evidence for a hominid presence in this part of the Maghreb. It is unfortunate that the Lower Pleistocene formations at Casablanca have not yielded an archaeological layer but only a few mammal remains. The first clear evidence for human activity is found in the late Lower Pleistocene, at the Thomas-Oulad Hamida Quarries complex.

\section{The Lower-Middle Pleistocene transition}

This period is best illustrated in Thomas Quarry 1, unit $\mathrm{L}$, where the oldest lithic assemblages of the Casablanca sequence are found in Late Lower Pleistocene deposits, ca. $1 \mathrm{Ma}$. They consist of Acheulean artefacts made of quartzite and flint (Raynal and Texier, 1989). The assemblage contains flakes struck from discoidal cores and polyhedrons. Besides chopping-tools, polyhedrons, and some cleavers, trihedrons and bifaces form the most characteristic elements among the tools (Fig. 2). They are often only partial and usually display lateral or lateral-distal concavities, which form the point of the bifaces (Fig. 3). A comparison of the probable use of the objects identified in our classification with experimental results leads us to conclude that the activities of stone working, hide slitting, heavy-duty butchery, and bone breaking were performed in unit L1, while stone working and light-duty butchery characterize unit L5.

The lowermost layers of Thomas 1 quarry have only yielded a few large mammals, left over by Homo erectus as food refuse, and rather badly preserved. Hippo, zebra, and gazelle have little biochronological significance, but the discovery in 1996 of a Kolpochoerus third molar suggests great antiquity. This Suid, widespread in Eastern and Southern Africa, was previously known in North Africa only in Plio-Pleistocene sites, the youngest of them being Aïn Hanech, a locality which is certainly of Lower Pleistocene age, perhaps close to 1.2 Ma. Kolpochoerus is absent from all other levels in Thomas/Oulad Hamida quarries, and from Tighenif, an Algerian locality whose age is close to the Lower/Middle Pleistocene boundary. Micromammals, although also rare, tend to confirm the great age of level L. There are two species of Gerbillus. The larger is of the size of G. grandi known in other levels of the Thomas 1 quarry but with a very broad $\mathrm{M} / 1$, and it is certainly specifically distinct; the smaller species is also distinct from the similar-sized G. minutus, G. jebileti, or $G$. campestris. A lower $\mathrm{M} / 1$ of Paraethomys has the anterior lobe transversal instead of $\mathrm{V}$-shaped as in all other Middle Pleistocene species, and it looks more like $P$. mellahe Ameur, from Oued Mellah, a locality older than Tighenif. The absence of Ellobius, an Arvicolid present at Tighenif also supports an age greater than that of this locality. On the whole, the fauna from level L demonstrates a Lower Pleistocene age of perhaps $1 \mathrm{Ma}$, in full 


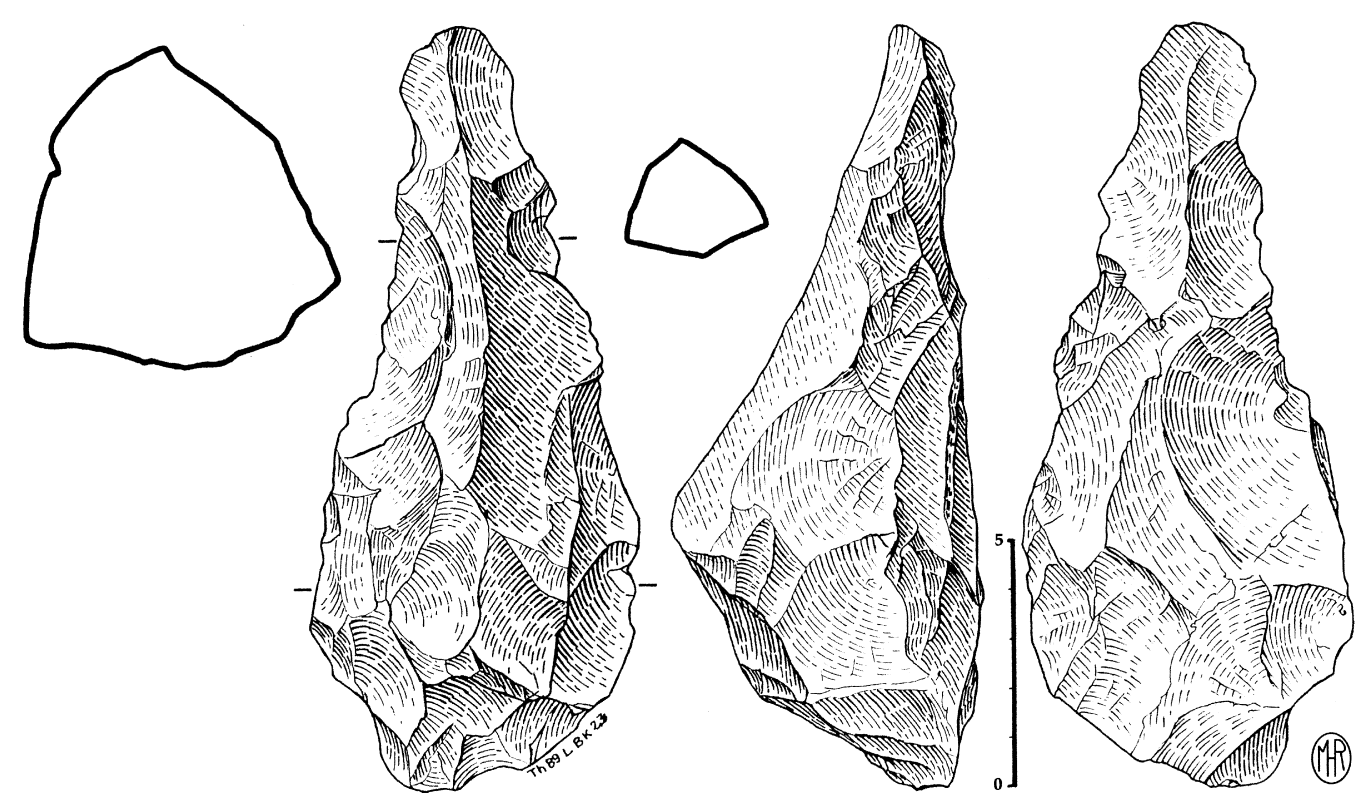

Fig. 2. Casablanca, Thomas 1 Quarry 1, Unit L, Lower Acheulian, classical trihedron made of quartzite.
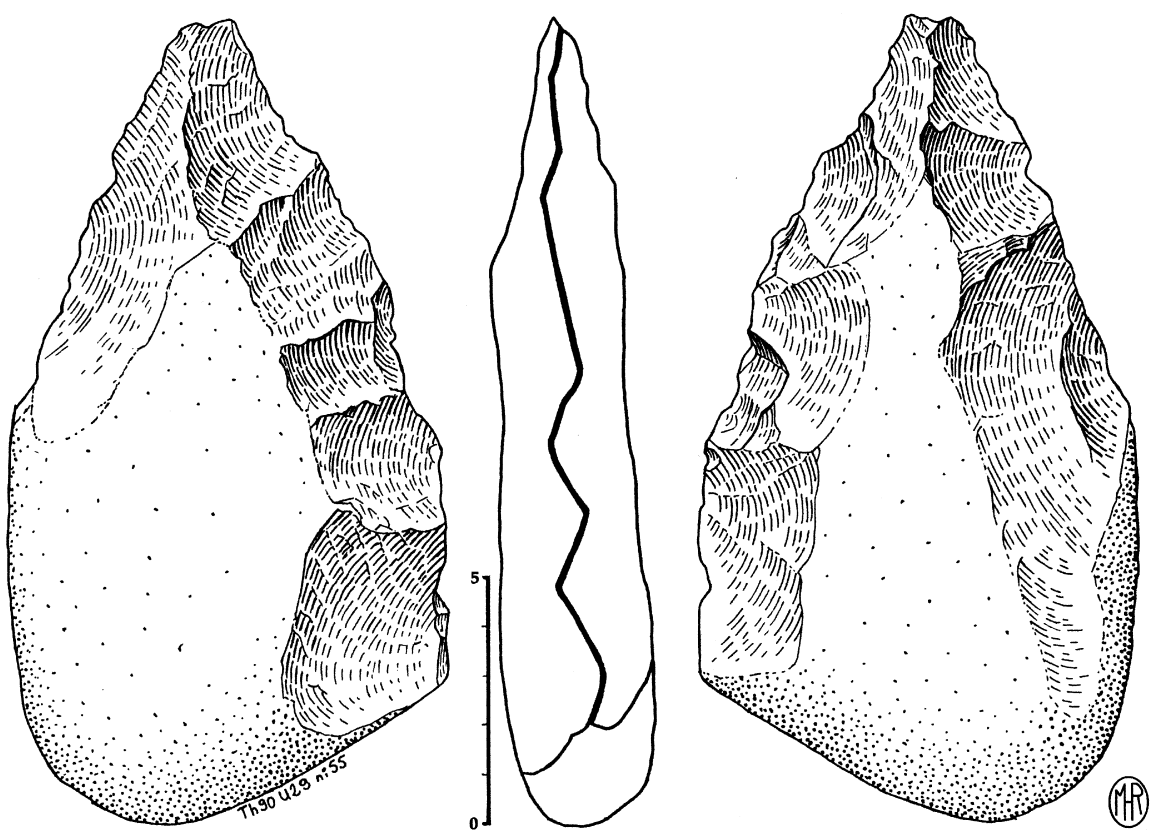

Fig. 3. Casablanca, Thomas 1 Quarry, Unit L, Lower Acheulian, partial biface on quartzite flat pebble.

accordance with the typology and technology of the artefacts, and with the paleomagnetic data obtained by Sevket Sen.

\section{Middle Pleistocene and the Acheulean sequence}

Middle Pleistocene levels are represented in the Oulad Hamida 1 Quarry. The Rhino Cave has yielded a rich collection of micro- and macro-mammals indicating a rather open and dry environment, associated with a rich Acheulean assemblage, and is now one of the best reference levels for this period in North Africa (Geraads, 1993b; Raynal et al., 1993; Rhodes et al., 1994). The abundant remains of white rhinoceros suggest specialized hunting by hominids, though scavenging cannot be discounted. Compared with the local Early Acheulean, an increase in discoidal cores and flake production is observed, cleavers are rare, while bifacial pieces are larger, characterized by convex and/or concave edges that 

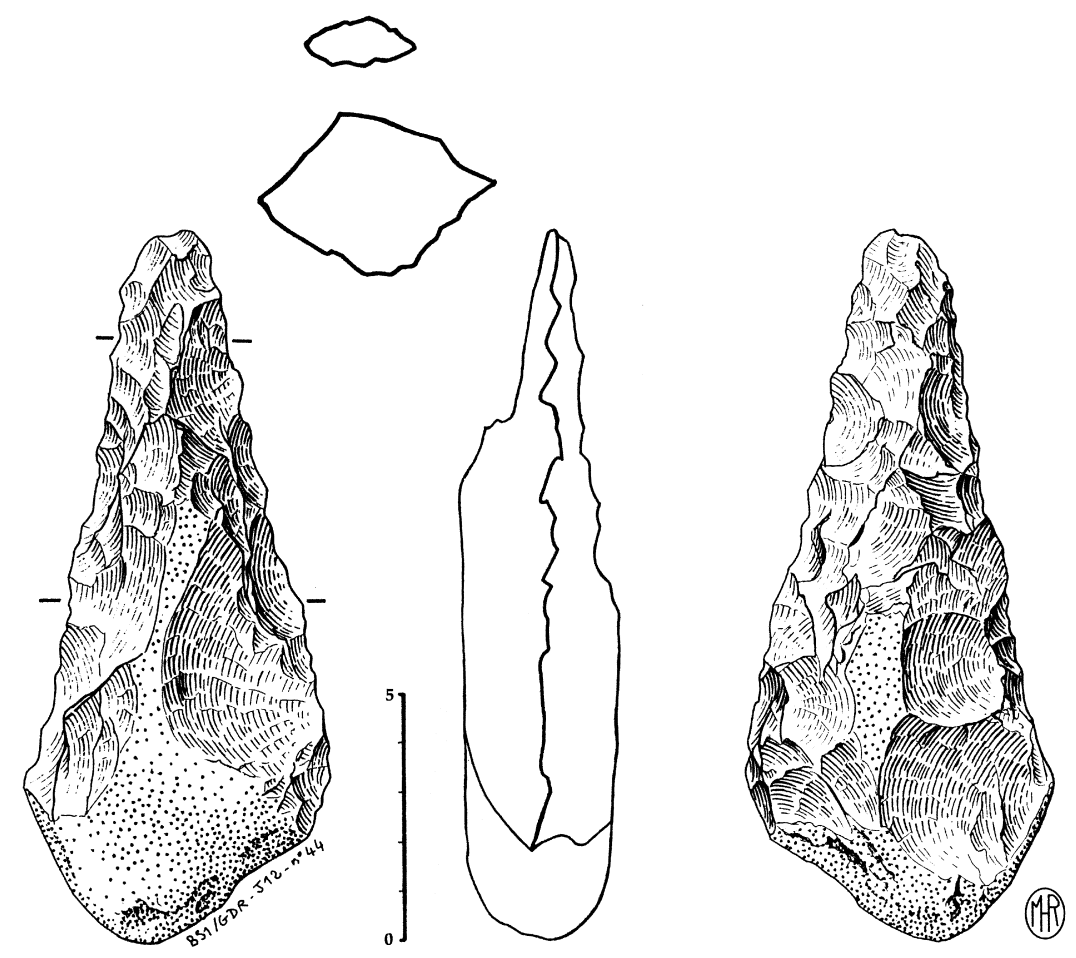

Fig. 4. Casablanca, Oulad Hamida 1 Quarry, Rhinoceros Cave, Evolved Acheulian, lanceolate bifacial made of quartzite.

constitute a pointed extremity (Figs. 4 and 5). In total, 3485 artefacts were removed from the bottom layer of a $70 \mathrm{~m}^{2}$ excavation. Tools on flakes represent only $3.5 \%$ of the assemblage and notches and denticulates predominate, the others being different types of scrapers and some multiple tools. Stone working was important in this site, as were hide cutting, light- and heavy-duty butchery, and bone breaking.

The assemblage recovered in a $65 \mathrm{~m}^{2}$ excavation of the Hominid level at Thomas Quarry 1 is quite different from the series of the Rhino Cave bottom unit, as it is dominated by flaked pebbles. It is, however, comparable to the (too) small series from the Rhino Cave top unit and series collected at the time of the discovery of the Homo jaw in 1969. Geological studies demonstrate that this assemblage was not in primary position but had been secondarily introduced into the cave, presumably removed from the entrance and transported by run-off, which mixed fauna remains and artefacts. The macro-fauna is similar in composition to that of Rhino Cave, although dominated here by carnivores (bears, hyenas and Canis) (Bernoussi, 1997). Three new teeth of Homo have recently been recovered in this level (Zouak, unpublished). This Thomas Quarry 1 Hominid Cave is vast, and some parts of the stratigraphy are still under study (Fig. 6). The preliminary dates, as well as biostratigraphic, and lithostratigraphic data point towards a greater antiquity than was previously estimated, with $0.4 \mathrm{Ma}$ as a minimum.

The relatively great antiquity of the two faunal sets from these caves is shown by their similarities with
Tighenif, and by the occurrence of several extinct species. Among the taxa shared with the Algerian site are probably the zebra Equus mauritanicus, the giant baboon Theropithecus oswaldi, and several species with lesser biochronological significance (Table 3). The OH1-Th1 faunal unit does not include some of the Lower Pleistocene survivors still present at Tighenif, such as the Suid Metridiochoerus, the antelope Hippotragus gigas, or the sabre-tooth cat Homotherium. However, Canis, the rat Mellivora, the lynx, the antelope Parmularius, and the hare Serengetilagus are all of now extinct (but then mostly new) species. The discovery of the micro-mammals allows refinement of the biochronological succession within this faunal unit. The best collection is from the Rhino Cave (OH1-GDR; Geraads, 1994) and samples have also been collected in several levels or spots in the Thomas 1 Quarry. The rodent fauna of this cave system, which is markedly distinct from that of level $\mathrm{L}$, is dominated by the Gerbillids, of which there are at least 4 species, confirming the aridity suggested by the abundance of Alcelaphines and gazelles among the bovids. Murids (Paraethomys, Praomys and Mus), Arvicolids (Ellobius) and Glirids (Eliomys) are less common. The earliest level is the pink breccia at the base of the Thomas 1 Cave, from where the Homo erectus mandible most probably comes. It yielded an Eliomys smaller than that at OH1-GDR, and also a small, perhaps new, species of the Gerbillid genus Meriones. Stratigraphic elements and absolute dating concur with placing these levels ca. $0.6 / 0.7 \mathrm{Ma}$, and this provides another new perspective. 

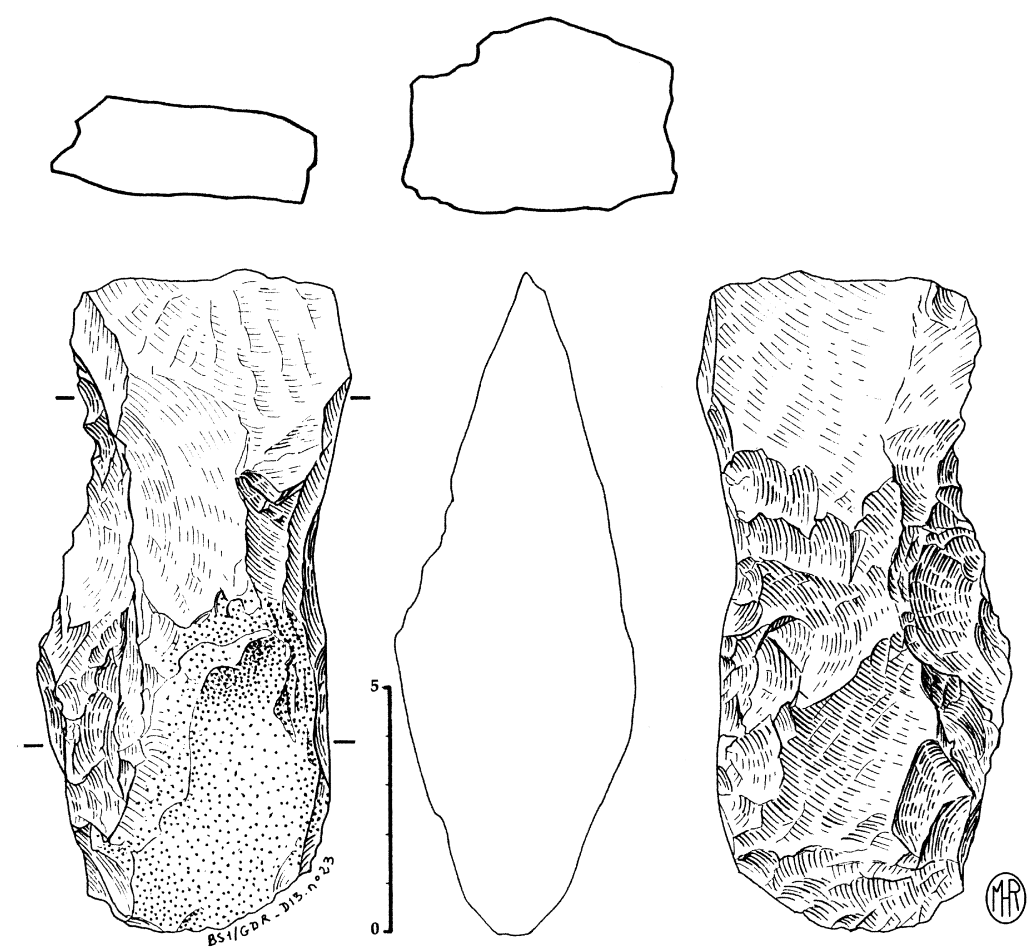

Fig. 5. Casablanca, Oulad Hamida 1 Quarry, Rhinoceros Cave, Evolved Acheulian, cleaver made of quartzite.

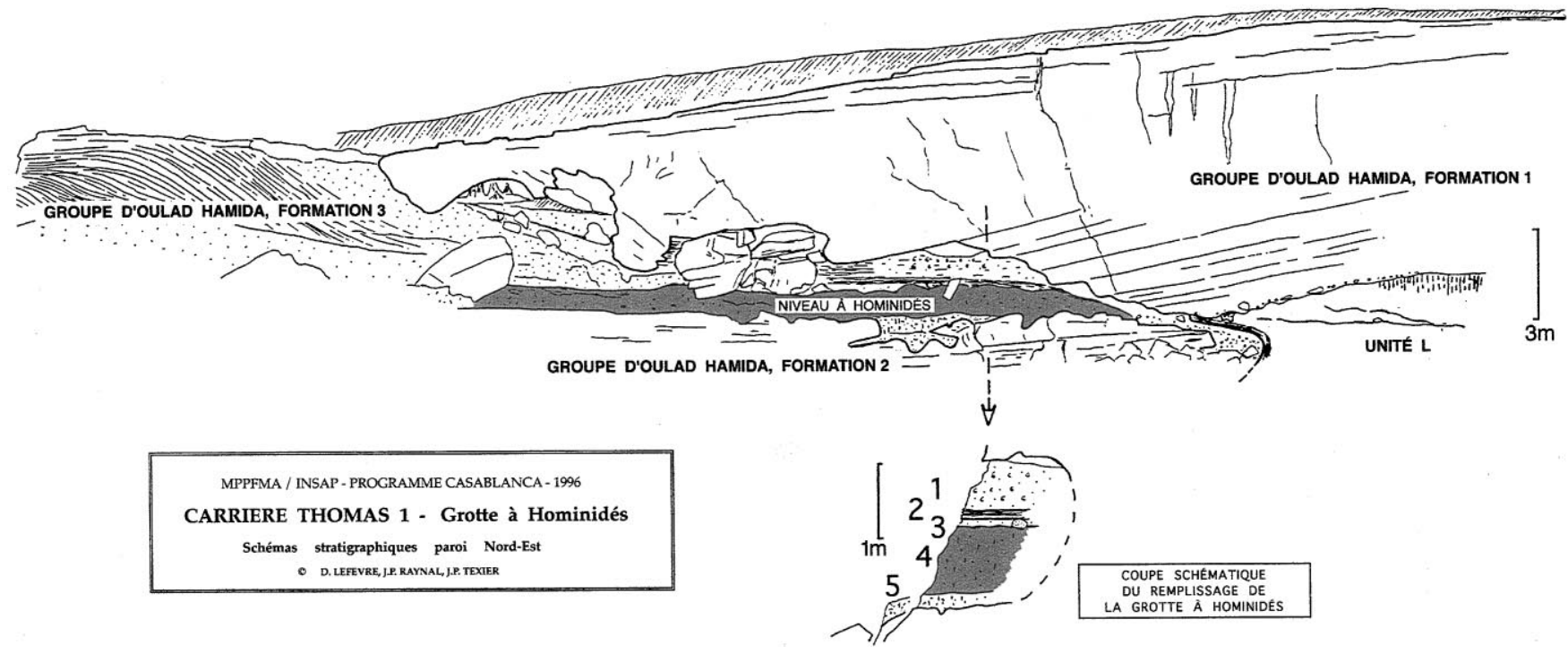

Fig. 6. Casablanca, Thomas 1 Quarry, Hominid Cave complex, Homo remains come from layer 4.

The recent phases of the Acheulean sequence are well illustrated in the classic Sidi Abderrahman localities. At Sidi Abderrahman-Extension, we observe an important use of block-fragments and the frequent recycling of rolled artefacts with multiple scars. Flakes are mainly produced from discoidal cores, and polyhedral forms are quite rare. Predetermined flakes are also rare, but these coexist with a diverse toolkit on flakes. Bifacial pieces are generally made on flakes and mostly display convex sides and tend towards ovate, even discoidal forms. Cleavers are rare here, perhaps as if they had become useless with the increase of new bifacial patterns. Stone working was important at this site, along with hide cutting, light-duty butchery, and bone breaking.

The uppermost part of the Acheulean sequence is represented at the Cap Chatelier site, with an age in excess of $200 \mathrm{ka}$ (according to optically stimulated luminescence dates by Rhodes, 1990). This assemblage is characterized 
Table 3

Detailed faunal lists of the different Thomas Quarries sites by Geraads

\begin{tabular}{|c|c|c|c|c|}
\hline OH1-GDR & $\begin{array}{l}\text { Th III-grotte à } \\
\text { H. erectus }\end{array}$ & Th I-ABCEF & $\begin{array}{l}\text { Th I-grotte à } \\
\text { H. erectus }\end{array}$ & Ternifine \\
\hline
\end{tabular}

Canis cf adustus

Lycaon $\mathrm{sp}$

Ursus bibersoni

Crocuta crocuta

Hyaena cf hyaena

Panthera cf leo

Felis cf silvestris

Lynx thomasi ${ }^{\mathrm{a}}$

Phacoch. cf africanus

Camelus sp

Bovini indet.

Parm. cf angusticornis

Parmularius sp?

\section{Gazella cf atlantica}

Equus cf mauritanicus

Ceratotherium simum

Eléphantidé indét. ${ }^{a}$

Therop. cf oswaldi

Mus hamidae

Praomys darelbeidae

Paraethomys tighennifae

Gerbillus grandis minor

G. cf campestris

Meriones maximus

M. maghreb. hamidae

E. atlanticus

Eliomys darelbeidae

Hystrix cf cristata

Serengetilagus raynali

Lepus cf capensis

Crocidura darelbeidae

C. cf tarfayaensis

Erinacéidé indet.

Chiroptére indet.

Sont de plus présents à Ternifine, mais non dans les carrières Thomas-Oulad Hamida:

Giraffa cf pomeli, Tragelaphus algericus, Hippotragus cf gigas, Kobus sp, Gazella dracula, Gazella sp
Canis cf adustus

Ursus bibersoni

P. cf africanus

Rabaticeras arambourgi
Connochaetes
taurinus prognu
Gazella $\mathrm{cf}$ atlantica
E. cf mauritanicus
C. simum

Th cf oswaldi

Hystrix cf cristata

\begin{abstract}
Mus hamidae
$P$. pomeli

P. tighennifae

Gerbillus grandis

G. cf campestris

Meriones maximus

M. maghrebianus

E. atlanticus

Eliomys sp

Hystrix cf cristata
\end{abstract}

Crocidura sp

P. cf africanus

Bovini indet.

Oryx sp

Alcelaphini indet

Connochaetes

taurinus prognu

Gazella cf atlantica

E. cf mauritanicus

C. simum

Eléphantidé indét.

Th of oswaldi

Mus sp

Praomys sp

P. tighennifae

G. grandis

M. maghrebianus

Eliobius sp

Eliomys sp

Hystrix cf cristata

Crocidura $\mathrm{sp}$
Canis adustus

Crocuta crocuta

Crocuta crocuta

Metridiochoerus compatus

C. thomasi

Bos cf bubaloides

Oryx cf gazella

P. ambiguus

Connochaetes

taurinus prognu

Gazella cf atlantica

Equus mauritanicus

C. simum

Loxodonta atlantica

Therop. oswaldi

P. eghrisae

P. tighennifae

G. cingulatus

G. major

Meriones maximus

M. maghrebianus

E. africanus

Hystrix cf cristata

Lepus cf capensis

Erinacéidé indet.

${ }^{\mathrm{a}}$ Th III-fiss seulement.

by production of predetermined flakes and thin, small bifaces, a diverse set of tools on flakes, and a very few cleavers. This Acheulean is the technical reservoir which, before the Last Interglacial, developed into Mousterian facies associated with modern humans, as demonstrated at Djebel Irhoud.

\section{Variability within the Acheulean}

The exploitation of the same raw materials throughout the Acheulean sequence at Casablanca allows a comparison of the technological characteristics of some representative series, presented here along the lines of the classification model developed on the basis of a study of the assemblages from Unit L of the Thomas quarry, briefly explained below. This model is based on the character of the working surfaces, their disposition and exploitation. It integrates dynamic aspects (sequences of production of flakes and of shaping, reduction of objects, re-use, etc.) and functional ones (specific morphology, transformation by usage, etc.). Seven main groups are discerned:

Group 1: flaking carried out by using cortical striking platforms;

Group 2: flaking from one non-cortical striking platform, possibly re-adjusted;

Group 3: flaking using two non-cortical striking platforms for one and the same working surface; 
Table 4

\begin{tabular}{ll}
\hline Chavaillon and Chavaillon (1981) & Classification in use \\
\hline Pebble tools & 1A, 2A, 2B1, 3, 4C, M1, M3 \\
Cores & 1A1, 2B1, 3, 4B, 4C, 5A, 6A, M4 \\
Choppers & 1A, 2A, 2B1, 3, 4C, M1 \\
Hammerstones & 7B, 7C, 7D \\
Broken pebbles & M1, M3, 7C \\
Polyhedrons & $5 \mathrm{~A}$ even 5B, 7A \\
Bolas & $7 \mathrm{~A}$ \\
\hline
\end{tabular}

Group 4: flaking using three to five non-cortical striking platforms for one and the same working surface. It contains most objects with multiple flake removals. Starting with flaking from cortical striking platforms and followed by an increase of flaked surfaces, this group contains the majority of complex and/or typical objects. The most complete bifaces as well as the best-exploited cores occur within this group;

Group 5: flaking from non-cortical striking platforms belonging to various working surfaces;

Group 6: exploitation/shaping of flakes and fragments;

Group 7: objects transformed by usage. With cores on flakes and fragments and tools on flakes, this testifies to the final stages of the knapping process. Items transformed by usage or re-utilization are at the origin of part of the observed assemblage variability.

The group subdivisions thus rest on technological and/or secondary morphological criteria (such as re-use of striking platforms, recurrence of flake removals, length of blanks - both artificial and natural - surface size of flake removals, and presence/absence of cortex). A comparison can be made with categories defined by Chavaillon and Chavaillon (1981) (Table 4).

The raw material, abundantly available in all sizes, allowed production of large flakes or voluminous fragments of pebbles and blocks. The only constraint was in the transport of heavy objects, making voluminous flaked items rare in the excavated sites. The various types of blanks introduced into the sites are clearly recognizable among the bifaces of the various series. The variability of lithic assemblages is well documented, following recent excavations in Thomas Quarry 1 units L1 and L5 (TH1/L1, TH1/L5), Thomas Quarry 1 Hominid Cave (TH1/GH), Rhino Cave bottom unit (GDR), Bear Cave (GDO), Cap Chatelier, Sidi Abderrahman Extension (SAE), and Sidi Al Khadir open-air sites (Table 5).

The series demonstrate an alternation between industries rich or poor in bifacial artifacts, but all are supposed to belong to the Acheulean technocomplex (Fig. 7). This situation is similar to that observed throughout Africa and Europe. This variability can occur within a short period of sedimentary events (i.e. Unit L at Thomas Quarry 1). On the other hand, similarities and differences in the structure of the various assemblages may actually derive from other factors.

Among these, one can nevertheless discount access to raw materials; the sources are the same throughout the sequence and the composition of assemblages is remarkably stable from this point of view. El Hank quartzites dominate, available in pebbles or chunks; and flint, only available in small pebbles, is much less flaked. Thus, the stability of technological solutions observed throughout the sequence evidently derives from raw material quality, while the variability derives from other factors. The neat correlation between the number of flake removals and the number of striking platforms is a technological constant (a succession of $x$ flakes originating from one platform), verified in experiments and determined by the mechanical characteristics of the raw material.

Bifaces also bear witness to the increasing complexity of elementary modes of reduction and to a continuous technological enrichment in which earlier acquisitions reappear (the polyhedral proximal end, for example). The changes among the bifaces reflect, in our view, a morpho-functional development, relayed in time by

Table 5

\begin{tabular}{|c|c|c|c|c|c|c|c|c|c|c|c|c|}
\hline \multirow[t]{2}{*}{$\begin{array}{l}\text { Sites } \\
\text { Age est. }\end{array}$} & \multicolumn{2}{|c|}{$\begin{array}{l}\text { TH1/L1 } \\
>0.78 \mathrm{Ma}\end{array}$} & \multicolumn{2}{|c|}{$\begin{array}{l}\text { TH1/L5 } \\
<0.78 \mathrm{Ma}\end{array}$} & \multicolumn{2}{|c|}{$\begin{array}{l}\text { TH1/GH } \\
0.4 / 0.6 \mathrm{Ma} ?\end{array}$} & \multicolumn{2}{|c|}{$\begin{array}{l}\text { GDR } \\
0.4 / 0.6 \mathrm{Ma} ?\end{array}$} & \multicolumn{2}{|c|}{$\begin{array}{l}\text { GDO } \\
0.4 \mathrm{Ma}\end{array}$} & \multicolumn{2}{|c|}{$\begin{array}{l}\text { SAE } \\
<0.4 \mathrm{Ma}\end{array}$} \\
\hline & $n$ & $\%$ & $n$ & $\%$ & $n$ & $\%$ & $n$ & $\%$ & $n$ & $\%$ & $n$ & $\%$ \\
\hline \multicolumn{13}{|l|}{ Groups } \\
\hline 1 & 18 & 6.0 & 18 & 4.8 & 40 & 54.8 & 66 & 11.3 & 104 & 51.2 & 31 & 5.4 \\
\hline 2 & 56 & 18.8 & 79 & 21.2 & 17 & 23.3 & 82 & 14.0 & 15 & 7.4 & 62 & 10.7 \\
\hline 5 & 18 & 6.0 & 66 & 17.7 & 0 & 0.0 & 59 & 10.1 & 27 & 13.3 & 5 & 0.9 \\
\hline 6 & 36 & 12.1 & 97 & 26.0 & 0 & 0.0 & 156 & 26.6 & 25 & 12.3 & 181 & 31.4 \\
\hline 7 & 8 & 2.7 & 41 & 11.0 & 0 & 0.0 & 155 & 26.5 & 0 & 0.0 & 3 & 0.5 \\
\hline Total & 298 & 100 & 373 & 100 & 73 & 100 & 586 & 100 & 203 & 100 & 577 & 100 \\
\hline
\end{tabular}




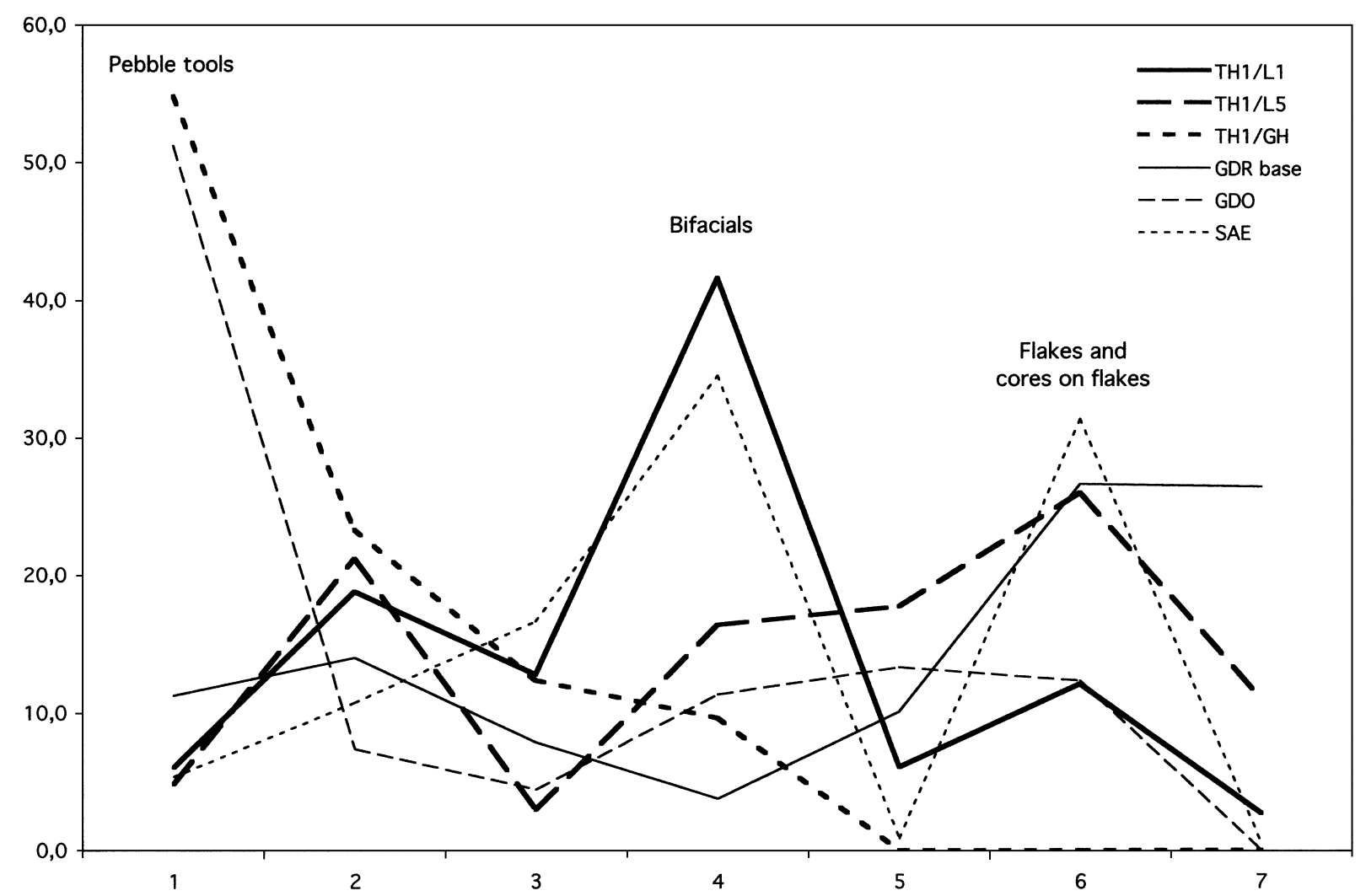

Fig. 7. Variation of major tools categories among the Acheulian sequence of Casablanca according to the technical categories described in Section 4.

more systematic production of flakes, including predetermined ones.

Some factors of variability might have had a natural origin, for instance, the selection of materials by redeposition, which had taken place in some layers. An example of this is Layer L1 at Thomas Quarry (a $1000 \mathrm{~m}^{2}$ surface was excavated), where small flakes and bone fragments have been washed or concentrated together, since the large sizes of the artefacts clearly indicate water-flow action. On the other hand, the smallest flakes are preserved in the eolian sands of Layer L5. Another factor is the limited area of some excavations (for example, the area excavated in Layer L5 at Thomas Quarry 1 does not exceed $25 \mathrm{~m}^{2}$ ).

Finally, possible cultural reasons for the various interrelationships among the industries must of course be considered. Whenever the use of raw materials is not in question, there may be a certain degree of variability connected with peculiar functional situations, such as adaptive reactions to environmental and/or micro-environmental changes, coinciding with regional or global climatic changes. Evidence for such variability in assemblages, tracking climatic fluctuations within a short time span, is illustrated by Layers L5 and L1 of Unit L at Thomas Quarry 1.
Variability in assemblages from sub-contemporaneous cave deposits at Thomas Quarry 1 and Oulad Hamida Quarry 1 may be considered from other points of view. Perhaps different carnivores may have acted in these sites as accumulators and scavengers, thus different meat resources were offered to hominids, and different tool kits were employed.

Finally, among the progressive transformations of assemblages, thresholds appear that could be linked with human evolutionary steps, reflect different biomechanical solutions, or simply mark different capacities for predetermining flaking actions. An example would be the remarkably regular change over time in the angle formed by the directions of the two flake removals that initiate two sequences of flake removals on one (or two) working surfaces. But this is another story, which is yet to be written.

In our opinion, the Casablanca sequence now offers useful data for comparisons with other African areas where hominids appeared and developed, and should be considered in the debate on the earliest occupation of Europe. For instance, we might view in it technological and biological evidence for supporting a multiple "Out of Africa" hypothesis and reconsider the debate about crossing the Mediterranean straits. 


\section{References}

Alemseged, Z., Geraads, D., 1998. Theropithecus atlanticus (Cercopithecidae, Mammalia) from the late Pliocene of Ahl al Oughlam, Morocco. Journal of Human Evolution 34, 609-621.

Bernoussi, R., 1997. Contribution à l'étude paléontologique et observations archéozoologiques pour deux sites du Pléistocène moyen du maroc atlantique: grotte à Hominidés de la carrière Thomas 1 et de la grotte des Rhinocéros de la carrière Oulad hamida 1 (Casablanca, Maroc). Thèse de l'Université de Bordeaux 1, no. 1711, 263 pp.

Biberson, P., 1961a. Le cadre paléogéographique de la Préhistoire du Maroc atlantique. Publications du Service des Antiquités du Maroc, Rabat, fascicule 16, $235 \mathrm{pp}$.

Biberson, P., 1961b. Le Paléolithique inférieur du Maroc atlantique. Publications du Service des Antiquités du Maroc, Rabat, fascicule $17,544 \mathrm{pp}$.

Chavaillon, J., Chavaillon, N., 1981. Galets aménagés et nucléus du Paléolithique inférieur. Mélanges offerts au Doyen L. Balout, ADPF, Paris, pp. 283-292.

Coiffait-Martin, B., 1991. Contribution des Rongeurs du Néogène d'Algérie à la biochronologie mammalienne d'Afrique nordoccidentale. Thèse Univ. Nancy-I, 389 pp.

Debénath, A., Raynal, J.P., Texier, J.P., 1982. Position stratigraphique des restes humains paléolithiques marocains sur la base des travaux récents. Comptes rendus de l'Académie des Sciences Paris, série II 294, 1247-1250.

El Graoui, M., 1994. Contribution à l'étude des formations littorales quaternaires de la région de Casablanca (Maroc): sédimentologie, microfaciès et minéraux lourds. Thèse de l'Université de Bordeaux I, no. 1100,288 pp.

Geraads, D., 1980. La faune des sites à Homo erectus des carrières Thomas (Casablanca, Maroc). Quaternaria 22, 65-94.

Geraads, D., 1998. Rongeurs du Mio-Pliocène de Lissasfa (Casablanca, Maroc). Géobios 31 (2), 229-245.

Geraads, D., 1993a. Kolpochoerus phacochoeroides (Thomas, 1884) (Suidae, Mammalia) du Pliocène supérieur de Ahl al Oughlam (Casablanca, Maroc). Géobios 26 (6), 731-741.

Geraads, D., 1993b. Middle Pleistocene Crocidura (Mammalia, Insectivora) from Oulad Hamida 1, Morocco, and their phylogenetic relationships. Proceedings, Koninklijike Nederlandse Akademie van Wetenschappen 96 (3), 281-294.

Geraads, D., 1994. Rongeurs et Lagomorphes du Pléistocène moyen de la "Grotte des Rhinocé-ros," Carrière Oulad Hamida 1 à Casablanca Maroc. Neue Jahrbuch Paläontologische Abh. 191 (2), 147-172.

Geraads, D., 1995. Rongeurs et insectivores (Mammalia) du Pliocène final de Ahl Al Oughlam (Casablanca, Maroc). Géobios 28 (1), 99-115.

Geraads, D., 1996. Le Sivatherium (Giraffidae, Mammalia) du Pliocène final d'Ahl al Oughlam (Casablanca, Maroc) et l'évolution du genre en Afrique. Paläontologische Zeitschrift, Stuttgart 70 (3-4), 623-629.

Geraads, D., 1997. Carnivores du Pliocène terminal de Ahl Al Oughlam (Casablanca, Maroc). Géobios 30 (1), 127-164.

Geraads, D., Amani, F., 1997. La faune du gisement à Homo erectus de l'Aïn Maarouf, près de El Hajeb (Maroc). L'Anthropologie 101 (3), 522-530.

Geraads, D., Amani, F., 1998. Bovidae (Mammalia) du Pliocène final d'Ahl al Oughlam, Casablanca, Maroc. Paläontologische Zeitschrift $72(1 / 2), 191-205$.

Geraads, D., Amani, F., Raynal, J.P., Sbihi-Alaoui, F.Z., 1998. La faune de Mammifères du Pliocène terminal d'Ahl Al Oughlam, Casablanca, Maroc. Comptes rendus de l'Académie des Sciences 326, 671-676.

Geraads, D., Beriro, P., Roche, H., 1980. La faune et l'industrie des sites à Homo erectus des carrières Thomas (Maroc). Précisions sur l'âge de ces hominidés. Comptes rendus de l'Académie des Sciences Paris, série II 291, 195-198.
Geraads, D., Metz-Muller, F., 1999. Proboscidea (Mammalia) du Pliocène final d'Ahm-Al-Oughlam (Casablanca, Maroc). Neues Jahrbuch für Geologie und Paläontologie Monatshefte, fasc. 1, pp. 52-64.

Gigout, M., 1956. Recherches sur le Pliocène et le Quaternaire atlantiques marocains. Travaux de l'Institut Scientifique Chérifien, Série Géologie et Géographie Physique, no. 5, 94 pp.

Lecointre, G., 1952. Recherches sur le Néogène et le Quaternaire marins de la côte atlantique du Maroc. Notes et mémoires du Service Géologique du Maroc, no. 99, t. 1: stratigraphie, 198 pp. and t. 2: paléontologie, $172 \mathrm{pp}$.

Lefevre, D., Texier, J.P., Raynal, J.P., Occhiettti, S., Evin, J., 1994. Enregistrements-réponses des variations climatiques du Pléistocène supérieur et de l'Holocène sur le littoral de Casablanca (Maroc). Quaternaire 5 (3-4), 173-180.

Neuville, R., Ruhlman, A., 1941. La place du paléolithique ancien dans le Quaternaire marocain. Hespéris VIII.

Occhietti, S., Raynal, J.P., Pichet, P., Texier, J.P., 1993. Aminostratigraphie du dernier cycle climatique au Maroc atlantique, de Casablanca à Tanger. Comptes rendus de l'Académie des Sciences Paris, série II $317,1625-1632$.

Raynal, J.P., Geraads, D., 1993. Problème patrimonial qui se pose à Casablanca au Maroc. In: L'objet archéologique africain et son devenir, CNRS Ed., pp. 49-55.

Raynal, J.P., Geraads, D., Magoga, L., Elhajraoui, A., Texier, J.P., Lefevre, D., Sbihi-Alaoui, F.Z., 1993. La grotte des Rhinocéros (Carrière Oulad Hamida 1, anciennement Thomas III, Casablanca), nouveau site acheuléen du Maroc atlantique. Comptes rendus de l'Académie des Sciences Paris, série II 316, 1477-1483.

Raynal, J.P., Lefevre, D., Geraads, D., El Graoui, M., 1999. Contribution du site paléontologique de Lissasfa (Casablanca, Maroc) à une nouvelle interprétation du Mio-Pliocène de la Méseta. Comptes rendus de l'Académie des Sciences Paris, Sciences de la terre et des planètes 329, 617-622.

Raynal, J.P., Magoga, L., Sbihi-Alaoui, F.Z., Geraads, D., 1995. The earliest occupation of Atlantic Morocco: the Casablanca evidence. In: Roebroeks, W., van Kolfschoten, T. (Eds.), The Earliest Occupation of Europe. University of Leiden, 1996, pp. 255-262.

Raynal, J.P., Texier, J.P., 1989. Découverte d'Acheuléen ancien dans la carrière Thomas I à Casablanca et problème de l'ancienneté de la présence humaine au Maroc. Comptes rendus de l'Académie des Sciences Paris, série II 308, 1743-1749.

Raynal, J.P., Texier, J.P., Geraads, D., Sbihi-Alaoui, F.Z., 1990. Un nouveau gisement plio-pléistocène en Afrique du Nord: Ahl Al Oughlam (ancienne carrière Déprez) à Casablanca (Maroc). Comptes rendus de l'Académie des Sciences Paris, série II 310, 315-320.

Rhodes, E., Raynal, J.P., Geraads, D., Sbihi-Alaoui, F.Z., 1994. Premières dates RPE pour l'Acheuléen du Maroc atlantique (Grotte des Rhinocéros, Casablanca). Comptes rendus de l'Académie des Sciences Paris, série II 319, 1109-1115.

Stearns, C.E., 1978. Plio-pleistocene emergence of the Moroccan Meseta. Geological Society of America Bulletin 89, 1630-1644.

Texier, J.P., Lefevre, D., Raynal, J.P., 1994. Contribution pour un nouveau cadre stratigraphique des formations littorales quaternaires de la région de Casablanca. Comptes rendus de l'Académie des Sciences Paris, série II 318 (9), 1247-1253.

Texier, J.P., Raynal, J.P., Lefevre, D., 1985. Nouvelles propositions pour un cadre chronologique raisonné du Quaternaire marocain. Comptes rendus de l'Académie des Sciences, Paris, série II 301, 183-188.

Texier, J.P., Raynal, J.P., Lefevre, D., 1987. Essai de chronologie du Quaternaire marocain. Bulletin d'Archéologie marocaine, t. XVI, 1985-86, pp. 11-24. 